\title{
LOCAL ECONOMIC ACTIVITIES SERVING GOOD GOVERNANCE IN RURAL AREAS ${ }^{1}$
}

\author{
Henrietta Nagy \\ associate professor \\ Szent István University, Faculty of Economics and Social Sciences \\ E-mail: nagy.henrietta@gtk.szie.hu
}

\begin{abstract}
The aim of this study is to give an overview on the concepts and practices of governance and good governance in the world with the recent Hungarian research results. It has always an important issue how good governance can lead to the development and catching up of rural areas, how it can translate economic growth to the welfare of people. Good governance has been placed high on the agenda of development policies, since it is supposed to create an environment in which sustained economic growth becomes achievable. Therefore, good governance has key importance in the development of rural areas which are mainly disadvantaged regions of Hungary and their sustainable development is a must. However, based on their current resources and socio-economic status, rather recession can be observed instead of their development. Several studies have been made in relation to the development potentials of Hungarian rural areas, calling attention on endogenous development strategies. This paper intends to focus on the role of good governance in achieving the expected targets.
\end{abstract}

Keywords: rural development, governance, good governance, local players

JEL: R10, R58

LCC: HD 72-88

\section{Introduction}

The expression of governance basically means the process of decision-making and the process by which decisions are implemented (or not implemented). Governance focuses on the formal and informal actors involved in decision-making and implementing the decisions made. Governance also focuses on the formal and informal structures in place and implement the decisions. Government is one of the actors in governance. Other actors involved in governance vary depending on the level of government that is under discussion. In rural areas, for example, other actors may include influential land lords, associations of peasant farmers, cooperatives, enterprises, NGOs, research institutes, religious leaders, finance institutions political parties, the military etc. All actors other than government and the military are grouped together as part of the civil society (ttps://www.unescap.org/sites/default/files/good-governance.pdf).

The definition offered by Huther and Shah (2005) describes governance as "a multifaceted concept encompassing all aspects of the exercise of authority through formal and informal institutions in the management of the resource endowment of a state". While Kaufmann et al. (2011) define governance as "the traditions and institutions by which authority in a country is exercised." Their approach to governance was adopted by the World Bank and served as a basis

\footnotetext{
${ }^{1}$ „This work was created in commission of the National University of Public Service under the priority project KÖFOP-2.1.2-VEKOP-15-2016-00001 titled „Public Service Development Establishing Good Governance” and Szent István University.”
} 
for construction of the worldwide governance indicators which were employed in the empirical work of Siudek-Zawojska (2014).

Good governance practices can enable responsible and responsive governments, organisations as well as leaders to make the right decisions with the most effective outcomes. Good governance can be realized at family, community, local, national and international level. In this paper I intend to focus on the rural areas, especially in Hungary. Good governance should aim at the development of the rural areas, using their endogenous resources, thus achieving sustainable economic growth.

\section{Concepts of good governance}

Since good governance has been important in development strategies and decision-making structures globally, I collected some concepts from international literature to see the various approaches. According to the United Nations, Good Governance is measured by the eight factors of Participation, Rule of Law, Transparency, Responsiveness, Consensus Oriented, Equity and Inclusiveness, Effectiveness and Efficiency, and Accountability.

- Participation requires that all groups, particularly those most vulnerable, have direct or representative access to the systems of government. This manifests as a strong civil society and citizens with the freedom of association and expression.

- Rule of Law is exemplified by impartial legal systems that protect the human rights and civil liberties of all citizens, particularly minorities. This is indicated by an independent judicial branch and a police force free from corruption.

- Transparency means that citizens understand and have access to the means and manner in which decisions are made, especially if they are directly affected by such decisions. This information must be provided in an understandable and accessible format, typically translated through the media.

- Responsiveness simply involves that institutions respond to their stakeholders within a reasonable time frame.

- Consensus Oriented is demonstrated by an agenda that seeks to mediate between the many different needs, perspectives, and expectations of a diverse citizenry. Decisions needs to be made in a manner that reflects a deep understanding of the historical, cultural, and social context of the community.

- Equity and Inclusiveness depends on ensuring that all the members of a community feel included and empowered to improve or maintain their well being, especially those individuals and groups that are the most vulnerable.

- Effectiveness and Efficiency is developed through the sustainable use of resources to meet the needs of a society. Sustainability refers to both ensuring social investments carry through and natural resources are maintained for future generations.

- Accountability refers to institutions being ultimately accountable to the people and one another. This includes government agencies, civil society, and the private sector all being accountable to one another as well (http://creativelearning.org/blog/2016/11/08/what-is-good-governance/).

In addition, in the European Union, 12 principles have recently been defined for the good democratic governance by the Centre of Expertise for Local Government Reform as follows:

1. Participation, Representation, Fair Conduct of Elections

2. Responsiveness

3. Efficiency and Effectiveness

4. Openness and Transparency 
5. Rule of Law

6. Ethical Conduct

7. Competence and Capacity

8. Innovation and Openness to Change

9. Sustainability and Long-term Orientation

10. Sound Financial Management

11. Human Rights, Cultural Diversity and Social Cohesion

12. Accountability

Local authorities that apply the 12 principles may be awarded the European Label of Governance' Excellence (ELoGE) (https://www.coe.int/en/web/good-governance/home). As it can be seen, there are common principles in the abovementioned definitions e.g. rule of law, accountability, participation, transparency, efficiency, responsiveness etc., thus we can see that in the focus of good governance the citizens must be found, how to involve them in developments that serve their needs in a transparent way.

We might agree that good government and good governance cover different issues and methods. For example, according to La Porta et al. (1999) good governance means good for economic growth; for Huther and Shah (2005) it means good for quality of life enjoyed by citizens; for Diamond (2013) it is that promotes democracy and delivers broad improvement in people's life, fights against corruption and power abuse and strengthens the rule of law. Taking these into consideration, we can see the correlation between good governance and spatial development that also aims at the improvement of the quality of life of citizens in the regions.

Grindle (2004) says that the good governance agenda is unrealistically long and growing longer over time. Among the multitude of governance reforms that "must be done" to encourage development and reduce poverty, there is little guidance about what's essential and what's not, what should come first and what should follow, what can be achieved in the short term and what can only be achieved over the longer term, what is feasible and what is not. If more attention is given to sorting out these questions, "good enough governance" may become a more realistic goal for many countries faced with the goal of reducing poverty. Working toward good enough governance means accepting a more nuanced understanding of the evolution of institutions and government capabilities; being explicit about trade-offs and priorities in a world in which all good things cannot be pursued at once; learning about what's working rather than focusing solely on governance gaps; taking the role of government in poverty alleviation seriously; and grounding action in the contextual realities of each country.

The innovation in the approach of good governance means that social actors outside the government are involved in governing, thus sharing the responsibility. One of the major critical views on this also related to such, since accountability criterion and democratic responsibility relates are tarnished. Gábor G. Fodor and István Stumpf (2008) pointed out the different focuses in the various approaches considered by good governance.

\section{Good governance indicators}

One of the most well-known indicator on governance is the Worldwide Governance Indicators (WGI) used by the World Bank. They organize and synthesize data reflecting the views of thousands of stakeholders worldwide, including respondents to household and firm surveys, and experts from nongovernmental organizations, public sector agencies, and providers of commercial business information. The latest update of the WGI is based on 35 data sources from 33 organizations around. 
The Worldwide Governance Indicators (WGI) project reports aggregate and individual governance indicators for over 200 countries and territories over the period 1996-2016, for six dimensions of governance. The WGI authors define governance as the traditions and institutions by which authority in a country is exercised. This includes the process by which governments are selected, monitored and replaced; the capacity of the government to effectively formulate and implement sound policies; and the respect of citizens and the state for the institutions that govern economic and social interactions.

1. Voice and Accountability: the extent to which a country's citizens are able to participate in selecting their government, as well as freedom of expression, freedom of association, and a free media.

2. Political Stability and Absence of Violence/Terrorism: the likelihood that the government will be destabilized by unconstitutional or violent means, including terrorism.

3. Government Effectiveness: the quality of public services, the capacity of the civil service and its independence from political pressures; and the quality of policy formulation.

4. Regulatory Quality: the ability of the government to provide sound policies and regulations that enable and promote private sector development.

5. Rule of Law: in and abide by the rules of society, including the quality of contract enforcement and property rights, the police, and the courts, as well as the likelihood of crime and violence.

6. Control of Corruption: the extent to which public power is exercised for private gain, including both petty and grand forms of corruption, as well as "capture" of the state by elites and private interests.

These aggregate indicators combine the views of a large number of enterprise, citizen and expert survey respondents in industrial and developing countries. They are based on over 30 individual data sources produced by a variety of survey institutes, think tanks, nongovernmental organizations, international organizations, and private sector firms (http://info.worldbank.org/governance/wgi/\#home). The WGI reflects the subjective opinion based on various surveys (carried out by households, company surveys, experts in private sector, NGOs and state sector agencies).

The six composite WGI measures are useful as a tool for broad cross-country comparisons and for evaluating broad trends over time. However, they are often too blunt a tool to be useful in formulating specific governance reforms in particular country contexts. Such reforms, and evaluation of their progress, need to be informed by much more detailed and country-specific diagnostic data that can identify the relevant constraints on governance in particular country circumstances. The WGI are complementary to a large number of other efforts to construct more detailed measures of governance, often just for a single country. Users are also encouraged to consult the disaggregated individual indicators underlying the composite WGI scores to gain more insights into the particular areas of strengths and weaknesses identified by the data.

Many policymakers and civil society groups use the WGI to monitor performance and advocate for governance reform. The WGI are also used by aid donors who recognize that the quality of governance is an important determinant of the success of development programs. Scholars, too, use the indicators in their empirical research on the causes and consequences of good governance. The WGI show that governance can in fact be measured systematically across countries. And this evidence-based approach yields important insights.

Apart from the World Bank statistics, there are only a few empirical researches for the CEE countries. One of them is a study according to Siudek-Zawojska (2014) saying is that "building 
strong, transparent government and establishing institutions of good governance were placed high on the political and academic agenda for reforming the EU's post-socialist countries; first time during their political and economic transition at the beginning of the 1990s, and then during the EU pre-accession periods. Relationship of various dimensions of state governance quality with economic growth and development in transition states (inter alia the current EU members from the CEE region) was empirically studied by Chousa et al. (2005), Redek and Sušjan (2005) and Próchniak (2011). Chousa and co-authors (2005) observed, in their study of 20 former socialist countries over the period 1990-2000, that institutional efficiency and democracy help their economies grow faster and achieve successful conditional convergence with the EU. Redek and Sušjan (2005), examining the interrelation between institutional quality and economic development in 24 transition countries over the 1995-2002 period, found the positive correlation between per capita GDP and the Heritage Foundation indexes of economic freedom. Próchniak (2011) employed the same indexes to analyze the impact of economic freedom on the economic growth in 10 EU's CEE member states from 1993 to 2009. His findings suggest that more economic freedom fosters economic growth in those countries." In spite of a large body of literature on the subject, there are limited empirical studies assessing the linkage of state governance institutions with economic and social performance of rural areas in the EU, especially in the new member states from the Central and Eastern Europe."

While overviewing the concepts and the measurement methods for good governance, we must not forget about the Good Governance Index - GGI by Nézőpont Intézet, Hungary (2018). This index evaluates and compares the government in $10 \mathrm{CEE}$ countries in the year 2017. The countries examined are Germany, Austria, Poland, Czech Republic, Slovakia, Slovania, Hungary, Croatia, Romania and Bulgaria. GGI considers good governance being interdependent with development and democracy, but as a separate expression. It is not the development level of the country or the performance in meeting the democratic criteria (even though they may be in relation to each other) that reflect the quality of government, but the operability and successfulness of the government. Government can be efficient if it is clear who takes the responsibility for what. The successful and responsible government is examined based on its economic, social and political achievements. Therefore, GGI is aggregated from 54 indicators in three dimensions (economic growth, quality of life and political stability).

In the methodology, the quantitative indicators for economic growth are the GDP growth, state debt, the volume of industrial production, services, current account, job vacancies, the competitiveness of wages and the corruption and the qualitative ones are competitiveness, budgetary issues, tax policy, industrial policy, service sector, trade, investment, wages and transparency. Taking all these into consideration, when thinking about development strategies for rural areas, we need to primarily focus on job creation, preferably on the production of local products. In order to create the highest value addition, we need to realize the most stages of production and sales locally using local resources. Based on the current situation of rural areas in Hungary, the top challenge strategy-makers face is the improvement of the human resource conditions. After mass migration of active and qualified labor force to more developed regions, people still living in the rural areas are usually underqualified and ageing not to mention the gradual decrease in the number of population.

When considering job creation and establishment of new businesses, the abovementioned features have to be taken into account. Therefore, such activities should be promoted in the rural regions that do not require qualified workforce but are built on endogenous resources. Furthermore, rural development should assist the local products to enter the international market and contribute to competitive business activities, including agribusiness (Káposzta, 2016). According to the Nemzeti Vidékstratégia 2012-2020 (2012), the first pillar of rural 
policy is the protection and sustainable use of landscape, natural values and resource. Sustainability approach does not refer to only natural values but economic activities should be financially sustainable as well. Natural endowments offer various opportunities even for people with low qualification, however, the education and training of rural people must always be a priority in development strategy. Collection and selection of herbs, forest fruits for further processing, collection of biomass (e.g. invasive species) for alternative energy use in public institutions, forestry, industrial sectors that require physical manpower can be activities done in rural areas to increase employment rate. Since businessmen from other regions usually do not tend to locate their business activities in such disadvantaged regions - despite of favourable tax policies, tax incentives, the long-term solution is to encourage local people to establish their own enterprises locally. In order to achieve that, human resource development is inevitable, entrepreneurship willingness as well as business, management, finance and other necessary knowledge has to be improved. Good governance in the rural areas should focus on creating living, business and public administration environment that is adjusted to the local conditions and needs. Local people should find their living in the rural areas that could stop the outmigration.

The quality of life indicators in the methodology of Nézöpont Institute include unemployment, employment, median wage, saving of the private sector, consumption, material security, crimes, subjective health condition and e-government. The qualitative indicators refer to responses to questions on unemployment, employment, integration, retirement policy, environment protection, family policy, healthcare, education, security policy and public services. It clearly proves that government and governance are not the same, being the latter a much broader scope. In my opinion, good governance along with area-specific rural development strategy could bring the expected improvement in the rural life, thus moderating the regional inequalities within the country.

\section{Conclusions}

Considering the achievements of the recent EU regional and rural development policies, we must see that they were not able to realize spectacular success in many rural areas, including Hungary. Several developments have been carries out but they resulted in improvements in certain settlements, while other settlements continued the recession. Good governance could supplement the activities in rural development strategy, creating a favourable environment for living and for businesses as well. If new jobs are created in the rural areas, people tend to spend more, if they can do it locally at local farmers and shops, it is even better. If local enterprises do marketable activities based on local resources and the market needs, they make profit, they tend to invest more locally that could result in common added value for the local community. Or another type of strategy can be to focus on the development of activities and services that are used by people living in other regions e.g. tourism. In that case people from other places visit the rural area, use the local services, buy the local products and thus contribute to local development. Income generated in such a way can be used to create more jobs, to spend on training or production or infrastructure. In my opinion, good governance has a key role also in bringing back people to the labour market, including the high number of minority living in the rural areas of Hungary. I also believe that good governance has to be realized jointly by the local government, local businesses, local population and the civil organizations. That would provide the high rate of representation and inclusiveness as well as involvement as detailed above in the concepts. Good governance may be easy to achieve and realize in practice in a multi-centered country where the counties, provinces are more autonomous, but in a onecentered country like Hungary, with the dominance of the capital, applying good governance methods is more difficult in rural areas that are out of the active blood-streams. 


\section{Acknowledgement}

„This work was created in commission of the National University of Public Service under the priority project KÖFOP-2.1.2-VEKOP-15-2016-00001 titled „Public Service Development Establishing Good Governance" and Szent István University."

\section{References}

1. Chousa, J.P., Khan, H.A., Melikyan, D. and Tamazian, A. (2005). Assessing institutional efficiency, growth and integration. Emerging Markets Review 6(1): 6984.

2. Diamond, L. (2013). The flow and ebb of democracy's third wave. The Mongolian Journal of International Affairs 18: 94-104.

3. Egri Zoltán-Kőszegi Irén Rita (2018): A gazdasági-társadalmi (komplex) térszerkezet kelet-közép-európai képe. TERÜLETI STATISZTIKA 58:(1) pp. 27-56. (2018)

4. Egri Zoltán (2017): Települési egészségegyenlőtlenségek a gazdasági fejlettség triadikus felbontása alapján. STUDIA MUNDI - ECONOMICA 4:(3) pp. 32-44. (2017)

5. G. Fodor Gábor \& Stumpf István (2008): Neoweberi állam és jó kormányzás. In Nemzeti Érdek. 2008/2. 5-26.

6. Grindle Merilee S. (2004): Good Enough Governance: Poverty Reduction and Reform in Developing Countries, https://doi.org/10.1111/j.0952-1895.2004.00256.x

7. Huther, J. and Shah, A. (2005). A simple measure of good governance. In Shah, A. (ed.), Public Services Delivery. Washington, DC: The World Bank, 39-61.

8. Kaufmann, D., Kraay, A. and Massimo, M. (2011). The Worldwide Governance Indicators: Methodology and analytical issues. Hague Journal on the Rule of Law 3(2): 220-246.

9. Káposzta J. (2016): Regionális összefüggések a vidékgazdaság fejlesztésében, Studia Mundi - Economica 3:(1) pp. 52-61.

10. Káposzta, J.- Nagy, A.-Nagy, H. (2013): Tourism infrastructure index and the distribution of development funds in statistical regions of Hungary Agrarnyi Vestnik Urala / Agrarian Bulletin of the Urals 2013:(12) pp. 80-83. (2013)

11. Káposzta, J.- Nagy, A.- Nagy, H. (2014): Efficiency of Hungarian regions in using the development funds for touristic purposes. Regionalnaja Ekonomika: Jug Rossii / Regional Economy: The South of Russia 4:(6)pp. 33-39. (2014)

12. Kozári József (2003): A mezőgazdasági szaktanácsadás finanszírozása a nyugateurópai országokban. GAZDÁLKODÁS 47:(5) pp. 67-71. (2003)

13. Kozári József-Tóth Krisztina (2011): The role of extension in the technical improvement of agricultural enterprises. NAUKOVIJ VISZNYIK 168:(3) pp. 34-39. (2011)

14. Kulcsár László-Kozári József (1998): A vidékfejlesztés új stratégiája Magyarországon. GAZDÁLKODÁS 42:(4) pp. 11-21. (1998)

15. La Porta, L., Lopez-de-Silanes, F., Shleifer, A. and Vishny, R. (1999). The quality of government. Journal of Law, Economics, and Organization 15(1): 222-279

16. Nagy, H.- Káposzta, J. (2010): Social and regional aspects of the structural and Cohesion Funds in the new EU member states between 2007-2013. In: Peter Bielik (szerk.): Economics, Social Policy and Citizenship in the European Union - Evidence of V4 Countries and Perspectives for Ukraine. 258 p. Nitra: Slovak University of Agriculture, Faculty of European Studies and Regional Development, 2010. pp. 148167. ISBN: 978-80-552-0448-2 
17. Nemzeti

Vidékstratégia

2012-2020

(2012), http://videkstrategia.kormany.hu/download/4/37/30000/Nemzeti\%20Vid\%C3\%A9ks trat $\% \mathrm{C} 3 \%$ A9gia.pdf

18. Nézöpont Intézet Nonprofit Kft: A közép-európai országok Jó Kormányzás Indexe (2018), Budapest, p. 136

19. Oláh I. - Ritter K.- Tóth T. (2013): The role of local communities in the disadvantaged rural areas In: Szendrő Katalin, Soós Mihály (szerk.) Proceedings of the 4th International Conference of Economic Sciences. 595 p. Kaposvár: Kaposvár University, 2013. pp. 547-553. (ISBN: 978-963-9821-62-0)

20. Próchniak, M. (2011). Determinants of economic growth in Central and Eastern Europe: The global crisis perspective. Post-Communist Economies 23(4): 449-468.

21. Redek, T. and Sušjan, A. (2005). The impact of institutions on economic growth: The case of transition economies. Journal of Economic Issues 39(4): 995-1027.

22. Tóth, T. (2008): Applying Methods and Processes Used in Regional Planning and Analysis to Regional, Rural and Small Area Development In: Peter Bielik, Bogdan Klepacki, Sergii Kvasha (szerk.) AGRICULTURAL MARKET AND TRADE: Evidence and perspektive of V4 Region and its Neighbour - Ukraine. 157 p. Warsaw: Editorial House Wies Jutra, 2008. pp. 105-119. (ISBN:83-89-503-62-x)

23. T. Siudek- A. Zawojska (2014): Quality of national governance and rural development: The case of the European Union countries, EAAE 2014 Congress 'AgriFood and Rural Innovations for Healthier Societies' August 26 to 29, 2014 Ljubljana, Slovenia

24. http://creativelearning.org/blog/2016/11/08/what-is-good-governance/

25. https://www.coe.int/en/web/good-governance/home

26. http://info.worldbank.org/governance/wgi/\#home 